\title{
KARAKTERISTIK FISIK JAGUNG P21 (Zea mays L.) TERMODIFIKASI MENGGUNAKAN METODE NIKSTAMALISASI DENGAN FORMULASI KALSIUM HIDROKSIDA Ca(OH $)_{2}$ DAN LAMA PERENDAMAN
}

\author{
Syarifah Dewi Noor Safitri ${ }^{1}$, M. Khoiron Ferdiansyah ${ }^{2}$, Enny Purwati Nurlaili ${ }^{2}$, \\ dan Iffah Muflihati ${ }^{2}$ \\ ${ }^{1}$ Mahasiswa Program Studi Teknologi Pangan, Universitas PGRI Semarang \\ ${ }^{2}$ Staf Pengajar Program Studi Teknologi Pangan, Universitas PGRI Semarang \\ Email: sdnsafitri@gmail.com
}

\begin{abstract}
ABSTRAK
Jagung merupakan salah satu serealia yang memiliki nilai ekonomi. Jagung dapat diolah menjadi produk setengah jadi yaitu tepung. Tepung jagung perlu dimodifikasi untuk memperbaiki sifat fisik sehingga mempunyai prospek sebagai bahan pangan dan bahan baku industri. Salah satu modifikasi yang digunakan adalah metode nikstamalisasi menggunakan kalsium hidroksida $\left(\mathrm{Ca}(\mathrm{OH})_{2}\right)$. Penelitian ini bertujuan untuk mengetahui pengaruh konsentrasi kalsium hidroksida $\left(\mathrm{Ca}(\mathrm{OH})_{2}\right)$ dan lama perendaman terhadap karakteristik fisik tepung jagung P21 nikstamal. Rancangan yang digunakan yaitu metode faktorial dengan dasar Rancangan Acak Lengkap (RAL). Faktor yang digunakan yaitu konsentrasi kalsium hidroksida 20\%; 40\% dan 60\%, serta lama perendaman 8 jam; 16 jam dan 24 jam. Hasil penelitian menunjukkan bahwa tepung jagung P21 yang dimodifikasi menggunakan metode nikstamal pada konsentrasi $60 \%$ dan lama perendaman 24 jam dapat meningkatkan nilai daya serap air sebesar $(2,18 \mathrm{~g} / \mathrm{g})$, dan kelarutan (13,04 \%) serta dapat menurunkan nilai tekstur (493,19 gr force), swelling power $(8,23 \mathrm{~g} / \mathrm{g})$, mengurangi tingkat kecerahan $\left(\mathrm{L}^{*}\right)(60,33)$, mengurangi tingkat kuning pada tepung jagung $(53,33)$.

Kata kunci-karakteristik fisik; jagung; kalsium hidroksida; nikstamalisasi
\end{abstract}

\section{PENDAHULUAN}

Jagung (Zea mays L.) merupakan salah satu tanaman pangan yang terpenting selain gandum dan padi. Luas panen jagung di Jawa Tengah untuk periode bulan Juni tahun 2017 mencapai 57.089 ha dengan produksi mencapai 325.980 ton. Sedangkan luas panen kumulatif dari bulan Januari sampai dengan bulan Juni 2017 adalah 349.350 ha dengan produksi 2.027.297 ton. Luas panen dan produksi jagung di Provinsi Jawa Tengah pada tahun 2017 di 35 Kota Madya dan Kabupaten yang terluas adalah di Kabupaten Grobogan yang menduduki urutan pertama luas panen sebesar 80.407 ha (Keadaan Tanaman Pangan Jawa Tengah Juni, 2017). Jagung termasuk komoditas strategis dalam pembangunan pertanian dan perekonomian Indonesia, mengingat komoditas ini mempunyai fungsi multiguna, baik untuk pangan maupun pakan (Rukmana, 2010).

Jagung berperan penting dalam perkembangan industri pangan. Seiring dengan meningkatnya kebutuhan akan produk-produk berbasis karbohidrat, diharapkan industri jagung semakin berkembang. Pemanfaatan jagung varietas P21 yang biasa digunakan sebagai pakan ternak bisa dilakukan modifikasi yang dapat digunakan sebagai bahan baku industri pangan yang akan memberikan nilai positif bagi komoditi jagung.

Nikstamalisasi merupakan proses pemasakan jagung dengan penambahan kalsium hidroksida sebanyak beberapa persen dari berat jagung yang dimasak. Tujuan nisktamalisasi adalah untuk memperbaiki sifat fisik dan kimia dari tepung (Rong dan Kang-Ning, 2009). Diversifikasi pangan olahan menjadi tepung bertujuan untuk meningkatkan nilai tambah dari jagung.

Jagung jenis P21 memiliki tekstur sangat keras yang menyebabkan jagung sulit untuk diproses, oleh karena itu perlu dilakukan penelitian mengenai penambahan gugus alkali kalsium hidroksida untuk mengurangi sifat keras dari jagung. Mekanisme kerja dari kalsium hidroksida adalah pada saat dilakukan perendaman terjadi penyerapan dan pendistribusian air yang lebih cepat dan memodifikasi lapisan luar biji jagung sehingga pecahan perikarp menjadi rapuh dan lengket (Rosentrater, 2005)

Salah satu alternatif pemanfaatan jagung yang telah mulai banyak diteliti dan dikembangkan adalah pengolahan tepung jagung. Akan tetapi, tepung jagung dari bahan baku P21 kurang menjadi pilihan untuk digunakan sebagai bahan baku makanan. Hal ini antara lain disebabkan sifat fisik jagung 
yang kurang menguntungkan seperti tekstur jagung yang keras sehingga sulit untuk diproses menjadi tepung. Pembuatan tepung jagung nikstamal sangat berguna karena tidak memerlukan proses pengolahan intensif dan dapat disimpan waktu yang lama tanpa mempengaruhi kualitas. Penelitian ini bertujuan untuk memperbaiki karakteristik fisik tepung jagung melalui modifikasi dengan proses nikstamalisasi.

\section{METODOLOGI PENELITIAN}

\section{A. Bahan dan Alat}

Bahan utama yang digunakan dalam modifikasi tepung jagung nikstamal yaitu jagung komoditas, jagung pipil kering dengan varietas hibrida P21 yang berasal dari daerah Grobogan, Jawa Tengah, kalsium hidroksida $\mathrm{Ca}(\mathrm{OH})_{2}$ (teknis), dan aquadest. Alat utama yang digunakan dalam penelitian antara lain mesin penggiling (grinder). Alat lain yang digunakan adalah JEOL JSM-65 1OLA, EYELA CA$1112 \mathrm{CCE}$, timbangan analitik (SHIMADZU), oven (MEMMERT), pipet volume (IWAKI), gelas ukur (IWAKI), tabung sentrifuge (IWAKI), sentrifuge (Gemmy PLC-05), vortex (Lab Dancer), hot plate (IKA C-MAG), $\mathrm{pH}$ meter (Eutech USA type $\mathrm{pH} 5+$ ), Grain Hardness Tester Model AGW dan chromameter.

\section{B. Rancangan Percobaan}

Penelitian ini menggunakan rancangan percobaan faktorial dengan dasar Rancangan Acak Lengkap (RAL). Variabel bebas yaitu konsentrasi larutan kalsium hidroksida $\left(\mathrm{Ca}(\mathrm{OH})_{2}\right)(20 \%, 40 \%$ dan 60\%) dan lama perendaman ( 8 jam , 16 jam dan 24 jam) serta dua sampel kontrol. Variabel terikat yaitu warna, tekstur, daya serap air, daya sera minyak, swelling power, kelarutan dan mikroskopis. Data hasil pengujian dianalisis dengan sidik ragam (Anova), Apabila hasil analisis tersebut menunjukkan berbeda nyata antara perlakuan, maka dilanjutkan dengan uji DMRT pada taraf 5\%, Analisis data dilakukan dengan menggunakan program SPSS 21,0.

\section{Analisis}

Analisis dilakukan terhadap sampel tepung jagung nikstamal. Kontrol yang digunakan adalah tepung jagung P21 dan tepung jagung komoditas. Analisis yang dilakukan pada penelitian ini yaitu warna dengan Chromameter (Hutching 1999), tekstur (Choy dkk., 2010), Swelling Power dan Kelarutan (Kainuma dkk., 1967), dan daya serap air (Valencia dkk, 2007 \& Ambriz dkk., 2008).

\section{HASIL DAN PEMBAHASAN}

\section{A. Warna}

Hasil uji statistik pada analisis warna (Tabel 1) menunjukkan bahwa nilai $\mathrm{L}^{*}$, $\mathrm{a}^{*}$, dan $\mathrm{b}^{*}$ pada semua perlakuan memiliki hasil yang berbeda nyata. Tingkat kecerahan $\left(\mathrm{L}^{*}\right)$ pada semua perlakuan bernilai positif berkisar 60,33-68,33 menunjukkan modifikasi tepung jagung nikstamal menuju putih. Pada perlakuan dengan semakin lama perendaman dan semakin banyak konsentrasi kalsium hidroksida menyebabkan tingkat kecerahan tepung jagung nikstamal menurun. Penurunan tingkat kecerahan $\left(\mathrm{L}^{*}\right)$ pada perendaman terjadi karena larutnya pigmen kuning pada jagung ke dalam media perendaman. Perlakuan pendahuluan berupa perebusan selama 30 menit dengan suhu $90^{\circ} \mathrm{C}$ dapat menurunkan tingkat kecerahan tepung akibat intensitas panas yang diterima selama proses pemanasan.

Tingkat kemerahan $\left(a^{*}\right)$ pada tepung jagung nikstamal yang dimodifikasi dengan lama perendaman dan penambahan kalsium hidroksida menunjukkan nilai negatif berkisar -11,33 sampai 16 yang berarti menunjukkan warna menuju hijau. Untuk tingkat kekuningan $\left(b^{*}\right)$ pada tepung jagung nikstamal yang telah dimodifikasi pada semua perlakuan menunjukkan nilai positif berkisar antara 48,33-64 yang menunjukkan warna tepung jagung nikstamal menuju warna kuning. Jika dibandingkan dengan kontrol jagung P21, kontrol jagung komoditas memiliki nilai ( $\left.\mathrm{b}^{*}\right)$ yang paling tinggi diantara semua perlakuan yaitu memiliki nilai sebesar 64 . Hal ini dikarenakan jagung komoditas memiliki betakaroten yang masih tinggi, dimana beta-karoten merupakan zat warna yang menghasilkan warna kuning. Hasil pengujian warna yang meliputi kecerahan $\left(L^{*}\right)$, nilai $a^{*}$ dan $b^{*}$ pada modifikasi tepung jagung nikstamal dapat dilihat pada Tabel 1. 
Jurnal Teknologi Pertanian Andalas Vol. 23, No.1, Maret 2019, ISSN 1410-1920, EISSN 2579-4019

Syarifah Dewi Noor Safitri, M. Khoiron Ferdiansyah, Enny Purwati Nurlaili, dan Iffah Muflihati

Tabel 1. Hasil Analisis Warna

\begin{tabular}{|c|c|c|c|c|c|c|c|c|c|}
\hline \multirow{3}{*}{$\begin{array}{c}\text { Lama } \\
\text { perendaman }\end{array}$} & \multicolumn{9}{|c|}{ Konsentrasi Kalsium Hidroksida } \\
\hline & \multicolumn{3}{|c|}{$\mathrm{A}_{1}$} & \multicolumn{3}{|c|}{$\mathrm{A}_{2}$} & \multicolumn{3}{|c|}{$\mathrm{A}_{3}$} \\
\hline & $\mathrm{L}^{*}$ & $a^{*}$ & $\mathrm{~b}^{*}$ & $\mathrm{~L}^{*}$ & $\mathrm{a}^{*}$ & $\mathrm{~b}^{*}$ & $\mathrm{~L}^{*}$ & $\mathrm{a}^{*}$ & $\mathrm{~b}^{*}$ \\
\hline \multirow[t]{2}{*}{$\mathrm{B}_{1}$} & $64,67 \pm$ & $-11,67 \pm$ & $54,33 \pm$ & $62,67 \pm$ & $-13,67 \pm$ & $53,00 \pm$ & $61,67 \pm$ & $-14, .33 \pm$ & $52,33 \pm$ \\
\hline & $0,57^{\mathrm{d}}$ & $2,08^{\mathrm{d}}$ & $1,52^{\mathrm{de}}$ & $0,67^{\mathrm{bcd}}$ & $0,57^{\mathrm{c}}$ & $1,00^{\mathrm{cd}}$ & $1,15^{\mathrm{abc}}$ & $0,57^{\mathrm{abc}}$ & $0,57^{\mathrm{bc}}$ \\
\hline \multirow[t]{2}{*}{$\mathrm{B}_{2}$} & $63,33 \pm$ & $-15,67 \pm$ & $55,33 \pm$ & $61,67 \pm$ & $-14,67 \pm$ & $48,33 \pm$ & $61,00 \pm$ & $-16,00 \pm$ & $51,00 \pm$ \\
\hline & $0,57^{\mathrm{cd}}$ & $0,57^{\mathrm{ab}}$ & $0,57^{\mathrm{e}}$ & $0,57^{\mathrm{abc}}$ & $0,57^{\mathrm{abc}}$ & $0,57^{\mathrm{a}}$ & $0,00^{\mathrm{ab}}$ & $0,00^{\mathrm{a}}$ & $0,00^{\mathrm{b}}$ \\
\hline \multirow[t]{2}{*}{$\mathrm{B}_{3}$} & $62,00 \pm$ & $-14,33 \pm$ & $52,33 \pm$ & $61,00 \pm$ & $-14,00 \pm$ & $51,00 \pm$ & 60,330 & $-14,00 \pm$ & $53,33 \pm$ \\
\hline & $2,00^{\mathrm{abc}}$ & $0,57^{\mathrm{abc}}$ & $0,57^{\mathrm{bc}}$ & $1,73^{\mathrm{ab}}$ & $1,00^{\mathrm{bc}}$ & $1,00^{\mathrm{b}}$ & $57 \pm^{\mathrm{a}}$ & $0,00^{\mathrm{bc}}$ & $1,15^{\mathrm{cd}}$ \\
\hline \multirow[t]{2}{*}{$\mathrm{K}_{1}$} & $61,67 \pm$ & $-11,33 \pm$ & $64,00 \pm$ & & & & & & \\
\hline & $2,30^{\mathrm{abc}}$ & $2,08^{\mathrm{d}}$ & $1,73^{\mathrm{g}}$ & & & & & & \\
\hline \multirow[t]{2}{*}{$\mathrm{K}_{2}$} & $68,33 \pm$ & $-15,33 \pm$ & $57,00 \pm$ & & & & & & \\
\hline & $0,57^{\mathrm{e}}$ & $0,57^{\mathrm{abc}}$ & $0,00^{\mathrm{f}}$ & & & & & & \\
\hline
\end{tabular}

Keterangan:

- Angka merupakan rata-rata 3 kali ulangan \pm standar deviasi

- Huruf notasi yang berbeda menunjukkan adanya beda nyata pada taraf signifikansi $(\alpha) 5 \%$

- A merupakan konsentrasi kalsium hidroksida 20\%

- $\mathrm{A}_{2}$ merupakan konsentrasi kalsium hidroksida $40 \%$

- $\mathrm{A}_{3}$ merupakan konsentrasi kalsium hidroksida $60 \%$

- $\mathrm{B}_{1}$ merupakan lama perendaman 8jam

- $\mathrm{B}_{2}$ merupakan lama perendaman 16jam

- $\mathrm{B}_{3}$ merupakan lama perendaman 24jam

- $\mathrm{K}_{1}$ merupakan kontrol jagung komoditas

- $\mathrm{K}_{2}$ merupakan kontrol jagung P21

- $L^{*}$ (derajat kecerahan) dengan nilai $0=$ hitam dan $100=$ putih

- $a^{*}$ (nilai positif berarti derajat kemerahan dan nilai negatif berarti derajat kehijauan)

- $b^{*}$ (nilai positif berarti derajat kekuningan dan negatif berarti kebiruan).

\section{B. Tekstur}

Tekstur diuji berdasarkan tingkat kemudahan patah suatu bahan pangan, dalam hal ini biji jagung setelah proses pengeringan atau sebelum penepungan. Besarnya tingkat patah pada biji jagung ditunjukkan dengan nilai Force break (kemudahan patah) terkecil. Makin mudah sampel biji jagung patah, maka nilai Force break semakin kecil yang berarti terkstur biji jagung tersebut makin baik (mudah patah). Hasil analisis fisik (tekstur) dapat dilihat pada Tabel 2.

Tabel 2. Hasil Analisis Tesktur (gr force)

\begin{tabular}{cccc}
\hline Lama Perendaman & \multicolumn{3}{c}{ Konsentrasi Kalsium Hidroksida } \\
\cline { 2 - 4 } & \multicolumn{1}{c}{$\mathrm{A}_{1}$} & \multicolumn{1}{c}{$\mathrm{A}_{2}$} & $\mathrm{~A}_{3}$ \\
\hline $\mathrm{B}_{1}$ & $760,35 \pm 37,33^{\mathrm{f}}$ & $719,56 \pm 3,11^{\mathrm{e}}$ & $688,29 \pm 26,51^{\mathrm{de}}$ \\
$\mathrm{B}_{2}$ & $712,77 \pm 6,36^{\mathrm{e}}$ & $679,80 \pm 2,94^{\mathrm{d}}$ & $609,78 \pm 5,09^{\mathrm{c}}$ \\
$\mathrm{B}_{3}$ & $609,44 \pm 6,63^{\mathrm{c}}$ & $562,19 \pm 32,08^{\mathrm{b}}$ & $493,19 \pm 12,99^{\mathrm{a}}$ \\
\hline $\mathrm{K}_{1}$ & $588,02 \pm 5,61^{\mathrm{bc}}$ & & \\
$\mathrm{K}_{2}$ & $1142,74 \pm 6,14^{\mathrm{g}}$ & & \\
\hline
\end{tabular}

Keterangan:

- Angka merupakan rata-rata 3 kali ulangan \pm standar deviasi

- Huruf notasi yang berbeda menunjukkan adanya beda nyata pada taraf signifikansi $(\alpha) 5 \%$

- A merupakan konsentrasi kalsium hidroksida $20 \%$

- $\mathrm{A}_{2}$ merupakan konsentrasi kalsium hidroksida $40 \%$

- A3 merupakan konsentrasi kalsium hidroksida $60 \%$

- $\quad B_{1}$ merupakan lama perendaman 8jam

- $\quad \mathrm{B}_{2}$ merupakan lama perendaman 16jam

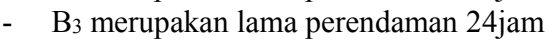

- $\mathrm{K}_{1}$ merupakan kontrol jagung komoditas

- $\mathrm{K}_{2}$ merupakan kontrol jagung P21

Hasil uji statistik pada uji tekstur yang dapat dilihat pada Tabel 2. menunjukkan bahwa konsentrasi kalsium hidroksida dan lama perendaman memberikan pengaruh yang nyata terhadap tekstur dari biji jagung nikstamal dan kontrol. Perbedaan tersebut disajikan dalam Tabel 2, menunjukkan bahwa terdapat perbedaan antara kedua sampel kontrol dan semua perlakuan. Tetapi, tidak berbeda nyata antara sampel dengan konsentrasi $20 \%$ pada perendaman 16 dan 24 jam serta pada 
perendaman 8 jam dengan konsentrasi 40\%. Semakin banyak konsentrasi yang ditambahkan dan semakin lama perendaman mengakibatkan nilai tekstur semakin menurun sehingga biji jagung semakin mudah untuk patah.

Menurut Lingga (1995) kalsium dari larutan $\mathrm{Ca}(\mathrm{OH})_{2}$ yang berpenetrasi kedalam jaringan jagung menjadi lebih kompak dengan terbentuknya ikatan baru antara kalsium dengan senyawa yang terdapat dalam jaringan jagung. Kemudahan biji jagung untuk mudah patah diduga karena dalam butiran pati jagung rantai-rantai amilosa dan amilopektin tersusun dalam bentuk semi kristal yang menyebabkan tidak larut dalam air, dengan adanya perlakuan pemanasan dan perendaman struktur kristal rusak dan rantai polisakarida akan mengambil posisi acak sehingga menyebabkan tergelatinisasi sempurna.

Menurut Ferdiansyah, dkk (2018) struktur kristalin dapat berkurang dengan semakin meningkatmya konsentrasi $\mathrm{NaOH}$. Kristalinitas menurun dikarenakan ikatan hidrogen intermiten dan intra-molekul selulosa selama proses ekstraksi dengan $\mathrm{NaOH}$. Sehingga, daerah amorf menjadi lebih banyak dari pada daerah kristalin, sehingga persen kristalinitas berkurang. Menurut Matz (1962), bila pati tergelatinisasi sempurna maka jumlah air yang keluar cukup besar sehingga akan terbentuk ronggarongga yang besar. Semakin tinggi konsentrasi kalsium hidroksida yang digunakan selama perendaman maka semakin mudah untuk biji jagung menjadi cepat patah. Hal ini diduga karena semakin tinggi konsentrasi alkali maka pericarp terlepas secara optimal sehingga memudahkan penetrasi air dan kalsium ke dalam biji jagung yang akan menghasilkan produk akhir yang semakin renyah.

\section{Daya Serap Air (Water Holding Capacity)}

Water Holding Capacity atau yang bisa disebut dengan daya serap air merupakan parameter yang menunjukkan kemampuan untuk menyerap air disekelilingnya untuk berikatan dengan partikel bahan (Jayusmar dkk., 2002). Hoover dan Sosulski (1986) menjelaskan bahwa perbedaan daya serap air bahan dapat disebabkan oleh perbedaan tingkat pengikatan gugus hidroksil yang membentuk ikatan hidrogen dan ikatan kovalen antar rantai pati. Semakin lama pemasakan jagung, semakin tinggi pula nilai daya serap air dari tepung jagung nikstamal. Hasil analisis daya serap air dapat dilihat pada Tabel 3.

Tabel 3. Hasil Analisis Daya Serap Air Tepung Jagung Nikstamal (g/g)

\begin{tabular}{|c|c|c|c|}
\hline \multirow[t]{2}{*}{ Lama Perendaman } & \multicolumn{3}{|c|}{ Konsentrasi Kalsium Hidroksida } \\
\hline & $\mathrm{A}_{1}$ & $\mathrm{~A}_{2}$ & $\mathrm{~A}_{3}$ \\
\hline $\mathrm{B}_{1}$ & $1,89 \pm 0,07^{\mathrm{a}}$ & $1,89 \pm 0,03^{a}$ & $1,90 \pm 0,02^{\mathrm{a}}$ \\
\hline $\mathrm{B}_{2}$ & $1,89 \pm 0,05^{\mathrm{a}}$ & $1,96 \pm 0,04^{\mathrm{a}}$ & $2,00 \pm 0,06^{\mathrm{a}}$ \\
\hline $\mathrm{B}_{3}$ & $1,97 \pm 0,01^{\mathrm{a}}$ & $2,01 \pm 0,09^{\mathrm{ab}}$ & $2,18 \pm 0,22^{b}$ \\
\hline $\mathrm{K}_{1}$ & $3,00 \pm 0,18^{c}$ & & \\
\hline $\mathrm{K}_{2}$ & $1,88 \pm 0,04^{\mathrm{a}}$ & & \\
\hline
\end{tabular}

Keterangan:

- Angka merupakan rata-rata 3 kali ulangan \pm standar deviasi

- Huruf notasi yang berbeda menunjukkan adanya beda nyata pada taraf signifikansi $(\alpha) 5 \%$

- $A_{1}$ merupakan konsentrasi kalsium hidroksida $20 \%$

- $A_{2}$ merupakan konsentrasi kalsium hidroksida 40\%

- A $3_{3}$ merupakan konsentrasi kalsium hidroksida $60 \%$

- $B_{1}$ merupakan lama perendaman 8jam

- $\quad B_{2}$ merupakan lama perendaman 16jam

- $\mathrm{B}_{3}$ merupakan lama perendaman 24jam

- $\mathrm{K}_{1}$ merupakan kontrol jagung komoditas

- $\mathrm{K}_{2}$ merupakan kontrol jagung P21

Hasil uji statistik pada analisis daya serap air yang dapat dilihat pada Tabel 3. menunjukkan bahwa konsentrasi kalsium hidroksida dan lama perendaman memberikan pengaruh nyata terhadap daya serap air tepung jagung nikstamal, dan terjadi interaksi antar 2 perlakuan tersebut. Tabel 3 menunjukkan bahwa nilai daya serap air tepung jagung nikstamal dengan lama perendaman 8 jam pada konsentrasi $20 \%, 40 \%$, dan $60 \%$ tidak terdapat perbedaan yang nyata dengan kontrol jagung P21 dan berbeda nyata dengan sampel kontrol jagung komoditas. Perendaman 16 jam pada konsentrasi $20 \%$, $40 \%$, dan $60 \%$ juga tidak terdapat perbedaan yang nyata dengan kontrol tepung jagung P21 dan berbeda nyata dengan sampel kontrol jagung komoditas serta tidak berbeda nyata dengan lama perendaman 8 jam pada semua konsentrasi. Perendaman 24 jam memiliki hasil yang berbeda nyata disemua konsentrasi tetapi tidak terdapat perbedaan yang nyata pada konsentrasi $20 \%$ dengan semua perlakuan 
pada perendaman 8 jam dan tidak terdapat perbedaan yang nyata dengan sampel tepung jagung kontrol jagung P21.

Perbedaan nilai daya serap air yang dihasilkan pada penelitian ini disebabkan oleh perbedaan konsentrasi kalsium hidroksida yang diberikan pada perlakuan dan lama perendaman jagung dalam proses nikstamalisasi. Rerata nilai daya serap air tertinggi didapat dari tepung jagung nikstamal dengan perlakuan lama perendaman 24 jam dan sampel dengan lama perendaman 16 jam pada konsentrasi $60 \%$.

Pemasakan jagung dapat meningkatkan gelatinisasi pati dan porositas tepung jagung yang dihasilkan. Pati yang tergelatinisasi memiliki gugus hidrofilik yang lebih banyak untuk berikatan dengan air dan porositas tepung juga dapat memfasilitasi penyerapan air (Ma dkk., 2011). Pendapat ini didukung oleh BeMiller dan Whistler (1997) yang menyatakan bahwa pati yang mengalami gelatinisasi akan kehilangan kristalinitasnya dan meningkat kemampuannya untuk mengikat air, sehingga semakin lama pemasakan jagung maka semakin tinggi pula tingkat gelatinisasi dan nilai daya serap air tepung jagung nikstamal.

\section{Swelling power}

Swelling power merupakan kenaikan volume dan berat maksimum pati selama mengalami pengembangan di dalam air (Balagopalan dkk., 1988). Ada 3 hal yang mempengaruhi swelling power yaitu pengaruh suhu dan lama pemanasan, serta kandungan amilosa dalam pati. Penambahan konsentrasi dan semakin lama perendaman yang diberikan menyebabkan nilai swelling power mengalami penurunan karena terdapat gugus amilosa yang terbentuk sehingga granula pati akan larut dalam air dan pasta yang terbentuk akan berkurang. Sifat swelling pada pati sangat tergantung pada kekuatan daya ikat dan sifat alami antar molekul di dalam pati, yang mana juga tergantung pada sifat alami dan kekuatan daya ikat dalam granula. Berbagai faktor yang menentukan daya ikat tersebut adalah (1) perbandingan amilosa dan amilopektin, (2) bobot molekul dari fraksi-fraksi tersebut, (3) distribusi bobot molekul,(4) derajat percabangan, (5) panjangan dari cabang molekul amilopektin terluar yang dapat berperan dalam kumpulan ikatan. Persentase nilai swelling power yang rendah diduga karena granula-granula pati yang terkandung di dalamnya sangat kompak. Kekompakan granula-granula pati tergantung pada perbandingan berat kandungan amilosa dan amilopektin serta sumber tumbuhannya (Haryadi, 1999). Daerah pada granula pati yang bangunannya kompak sukar ditembus oleh pengaruh dari luar. Sedikit air mungkin masuk ke dalam granula melalui daerah amorf tetapi tidak demikian pada daerah kristalin yang kompak sehingga daerah tersebut terhindar dari penggelembungan yang menyebabkan sukar untuk mengembang. Adanya peningkatan nilai swelling power ini disebabkan oleh melemahnya ikatan hidrogen pada granula pati. Selain itu peningkatan suhu pemanasan juga dapat meningkatkan nilai swelling power akibat terjadi kerusakan ikatan hidrogen intramolekuler dan meningkatkan gugus hidroksil bebas dalam granula sehingga molekul air yang berikatan semakin tinggi dan mengalami peningkatan pengembangan granula dalam air. Menurut Hoover and Hadziyev (1981) ketika sejumlah pati dipanaskan dalam jumlah air yang berlebih, struktur kristalinnya menjadi terganggu sehingga menyebabkan kerusakan pada ikatan hidrogen dan molekul hidrogen keluar dari grup hidroksil amilosa dan amilopektin. Hal ini menyebabkan terjadinya peningkatan swelling. Untuk mengetahui nilai swelling power dapat dilihat pada Tabel 5.

Tabel 5. Hasil Analisis Swelling Power Tepung Jagung Nikstamal (\%)

\begin{tabular}{clcl}
\hline \multirow{2}{*}{ Lama Perendaman } & \multicolumn{3}{c}{ Konsentrasi Kalsium Hidroksida } \\
\cline { 2 - 4 } & \multicolumn{1}{c}{$\mathrm{A}_{1}$} & \multicolumn{1}{c}{$\mathrm{A}_{2}$} \\
\hline $\mathrm{B}_{1}$ & $9,47 \pm 0,68^{\mathrm{cd}}$ & $8,95 \pm 0,66^{\mathrm{abc}}$ & $8,89 \pm 0,00^{\mathrm{abc}}$ \\
$\mathrm{B}_{2}$ & $8,95 \pm 0,42^{\mathrm{abc}}$ & $9,26 \pm 0,21^{\mathrm{bcd}}$ & $8,72 \pm 0,15^{\mathrm{abc}}$ \\
$\mathrm{B}_{3}$ & $8,36 \pm 0,06^{\mathrm{ab}}$ & $8,31 \pm 0,19^{\mathrm{ab}}$ & $8,23 \pm 1,21^{\mathrm{b}}$ \\
\hline $\mathrm{K}_{1}$ & $5,45 \pm 1,18^{\mathrm{a}}$ & \\
$\mathrm{K}_{2}$ & $9,88 \pm 1,23^{\mathrm{d}}$ & & \\
\hline
\end{tabular}

Keterangan:

- $\quad$ Angka merupakan rata-rata 3 kali ulangan \pm standar deviasi

Huruf notasi yang berbeda menunjukkan adanya beda nyata pada taraf signifikansi $(\alpha) 5 \%$

A 1 merupakan konsentrasi kalsium hidroksida 20\%

$\mathrm{A}_{2}$ merupakan konsentrasi kalsium hidroksida $40 \%$

A3 merupakan konsentrasi kalsium hidroksida $60 \%$

$\mathrm{B}_{1}$ merupakan lama perendaman $8 \mathrm{jam}$

$\mathrm{B}_{2}$ merupakan lama perendaman $16 \mathrm{jam}$ 
- B3 merupakan lama perendaman 24jam

- $\mathrm{K}_{1}$ merupakan kontrol jagung komoditas

- $\mathrm{K}_{2}$ merupakan kontrol jagung P21

Hasil uji statistik pada analisis swelling power yang dapat dilihat pada Tabel 5. Setiap perlakuan memiliki perbedaan yang nyata dengan sampel kontrol tepung jagung komoditas maupun sampel kontrol tepung jagung P21. Secara keseluruhan dengan penambahan kalsium hidroksida dan dengan dilakukan proses perendaman mengakibatkan nilai dari swelling power dari tepung jagung nikstamal mengalami penurunan. Konsentrasi dengan lama perendaman 8 jam pada penambahan konsentrasi $40 \%$ serta $60 \%$ tidak berbeda nyata dengan konsentrasi pada perendaman 16 jam dengan penambahan konsentrasi $20 \%$, dan $60 \%$. Konsentrasi dengan lama perendaman 24 jam pada penambahan kalsium hidroksida $20 \%$ dan $40 \%$ tidak berbeda nyata.

Kontrol sampel tepung jagung jenis P21 memiliki nilai swelling power yang paling tinggi jika dibandingkan dengan semua perlakuan. Hal ini karena gugus karbonil sangat berpengaruh pada degradasi amilosa, sehingga semakin meningkatnya degradasi amilosa maka pasta yang terbentuk akan semakin sedikit dan akan menurunkan nilai swelling power.

Penelitian Setiawan (2009) melaporkan bahwa nilai swelling power pati jagung berkisar 2,38$15,01 \%$. Persentase swelling power tepung jagung nikstamal pada penelitian ini berkisar antara 5,459, $88 \%$. Hal ini mengindikasikan bahwa tingkat swelling power tepung jagung nikstamal dalam penelitian ini lebih rendah dibandingkan dengan pati jagung diduga karena tepung jagung nikstamal mengandung lebih banyak serat dibandingkan dengan pati jagung. Menurut Goldsworth dan Fisher (1996), kandungan amilosa yang tinggi dalam pati menyebabkan rendahnya tingkat swelling.

\section{E. Kelarutan}

Kelarutan merupakan berat tepung terlarut dan dapat diukur dengan cara mengeringkan dan menimbang sejumlah supernatan (Balagopalang dkk., 1988). Kelarutan dan swelling power merupakan dua hal yang berkaitan dan terjadi pada saat gelatinisasi. Semakin banyak molekul amilosa yang keluar dari granula pati maka kelarutan semakin tinggi. Namun tidak selamanya kandungan amilosa berbanding lurus dengan kelarutan. Penurunan kelarutan pada tepung jagung nikstamal dengan lama perendaman 16 jam diduga akibat perubahan sifat pati yang semula hidrofilik menjadi hidrofobik. Menurut Xu dkk., (2004), hidrofobisitas pati meningkat dengan peningkatan panjang rantai karbon ditinjau dari kandungan pati. Selain itu, penurunan kelarutan juga diduga karena terjadi kompleks antara amilosa dengan gugus substituen dengan ikatan yang sangat kuat, sehingga menyebabkan terjadi pemerangkapan molekul air didalam molekul pati yang mengakibatkan daya mengembang meningkat dan mencegah molekul amilosa untuk terlarut dalam sistem yang menyebabkan daya larut menurun. Hasil analisis kelarutan modifikasi jagung nikstamal dapat dilihat pada Tabel 6

Tabel 6. Hasil Analisis Kelarutan (\%)

\begin{tabular}{clcl}
\hline Lama Perendaman & \multicolumn{3}{c}{ Konsentrasi Kalsium Hidroksida } \\
\cline { 2 - 4 } & \multicolumn{1}{c}{$\mathrm{A}_{1}$} & \multicolumn{1}{c}{$\mathrm{A}_{2}$} & \multicolumn{1}{c}{$\mathrm{A}_{3}$} \\
\hline $\mathrm{B}_{1}$ & $11,60 \pm 2,00^{\mathrm{b}}$ & $11,74 \pm 0,47^{\mathrm{b}}$ & $12,49 \pm 2,37^{\mathrm{b}}$ \\
$\mathrm{B}_{2}$ & $10,99 \pm 2,26^{\mathrm{b}}$ & $4,84 \pm 2,15^{\mathrm{a}}$ & $12,69 \pm 1,54^{\mathrm{b}}$ \\
$\mathrm{B}_{3}$ & $12,33 \pm 1,23^{\mathrm{b}}$ & $12,49 \pm 0,47^{\mathrm{b}}$ & $13,04 \pm 1,75^{\mathrm{b}}$ \\
\hline $\mathrm{K}_{1}$ & $40,54 \pm 2,43^{\mathrm{c}}$ & & \\
$\mathrm{K}_{2}$ & $10,48 \pm 1,33^{\mathrm{b}}$ & & \\
\hline
\end{tabular}

Keterangan:

- Angka merupakan rata-rata 3 kali ulangan \pm standar deviasi

- Huruf notasi yang berbeda menunjukkan adanya beda nyata pada taraf signifikansi $(\alpha) 5 \%$

- $A_{1}$ merupakan konsentrasi kalsium hidroksida $20 \%$

- $\mathrm{A}_{2}$ merupakan konsentrasi kalsium hidroksida $40 \%$

- A3 merupakan konsentrasi kalsium hidroksida $60 \%$

$\mathrm{B}_{1}$ merupakan lama perendaman 8jam

- $\mathrm{B}_{2}$ merupakan lama perendaman 16jam

$\mathrm{B}_{3}$ merupakan lama perendaman 24jam

- $\mathrm{K}_{1}$ merupakan kontrol jagung komoditas

- $\mathrm{K}_{2}$ merupakan kontrol jagung P21 
Hasil uji statistik pada analisis kelarutan yang dapat dilihat pada Tabel 6. menunjukkan tidak berbeda nyata pada semua perlakuan. Berdasarkan tabel 6 dapat dilihat bahwa dengan penambahan kalsium hidroksida dan lama perendaman dari semua sampel tidak terdapat perbedaan nyata dengan sampel kontrol tepung jagung P21 tetapi berbeda nyata pada perendaman 16jam dengan konsentrasi $40 \%$ dan sampel kontrol jagung komoditas. Semakin lama perendaman nilai kelarutan semakin meningkat tetapi mengalami penurunan pada perendaman 16 jam dengan konsentrasi $20 \%$ dan $40 \%$. Hal ini menunjukkan bahwa lama perendaman berkorelasi positif terhadap kelarutan tepung jagung nikstamal. Dengan adanya perlakuan perendaman maka akan terjadi subsitusi gugus hidrofilik ke dalam molekul tepung jagung nikstamal yang memperlemah ikatan internal tepung jagung (Miyazaki dkk., 2006) sehingga tepung jagung lebih mudah larut dalam air.

Secara garis besar dapat dilihat bahwa semakin lama perendaman jagung dalam proses nikstamalisasi maka nilai persentase kelarutan mengalami peningkatan. Kelarutan pun meningkat seiring meningkatnya suhu pemanasan. Menurut Singh dkk., (2005), kelarutan pati jagung berkisar 6 $20,3 \%$ pada suhu $90^{\circ} \mathrm{C}$. Sedangkan penelitian Setiawan (2009) melaporkan bahwa pada suhu pemanasan $90^{\circ} \mathrm{C}$ kelarutan pati jagung berkisar antara $9-12 \%$. Persentase kelarutan tepung jagung nikstamal pada penelitian ini berkisar antara $4,84-13,04 \%$ pada suhu $90^{\circ} \mathrm{C}$. Hal ini mengindikasikan bahwa nilai persentase kelarutan antara pati jagung dengan tepung nikstamal tidak berbeda jauh,walaupun dapat dilihat bahwa nilai kelarutan tepung jagung nikstamal lebih rendah dibandingkan dengan nilai kelarutan pati jagung.

\section{F. Analisis Mikroskopis}

Hasil pengamatan menggunakan mikroskop dengan konsentrasi $60 \%$ dan lama perendaman 24 jam serta dengan sampel kontrol tepung jagung P21 pada perbesaran 500X - 3000X menunjukkan bahwa morfologi granula pati tepung jagung nikstamal bervariasi dari polygonal sampai agak bulat atau oval. Bentuk dan ukuran granula akan dapat dilihat lebih jelas bila digunakan perbesaran 5000X (Whistler dkk., 1984). Pada konsentrasi 60\% dengan lama perendaman 24 jam dan sampel kontrol tepung jagung P21 memiliki bentuk polygonal. Pada konsentrasi $60 \%$ dengan perendaman 24 jam bentuk granula sudah mulai pecah. Sedangkan perbesaran 5000X pada sampel tepung jagung kontrol memiliki bentuk granula yang masih belum pecah atau granula belum keluar. Untuk mengetahui bentuk granula dapat dilihat pada Gambar 1 dan 2.

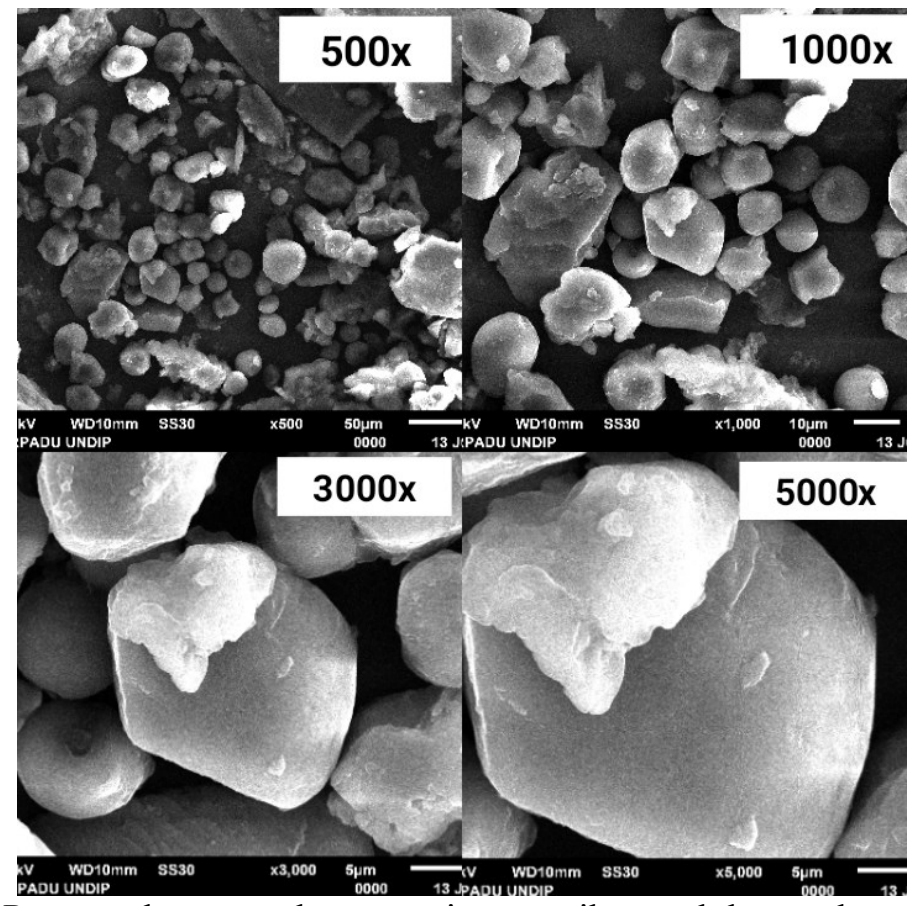

Gambar 1. Penampakan granula tepung jagung nikstamal dengan konsentrasi $60 \%$ dan lama perendaman $24 \mathrm{jam}$ 


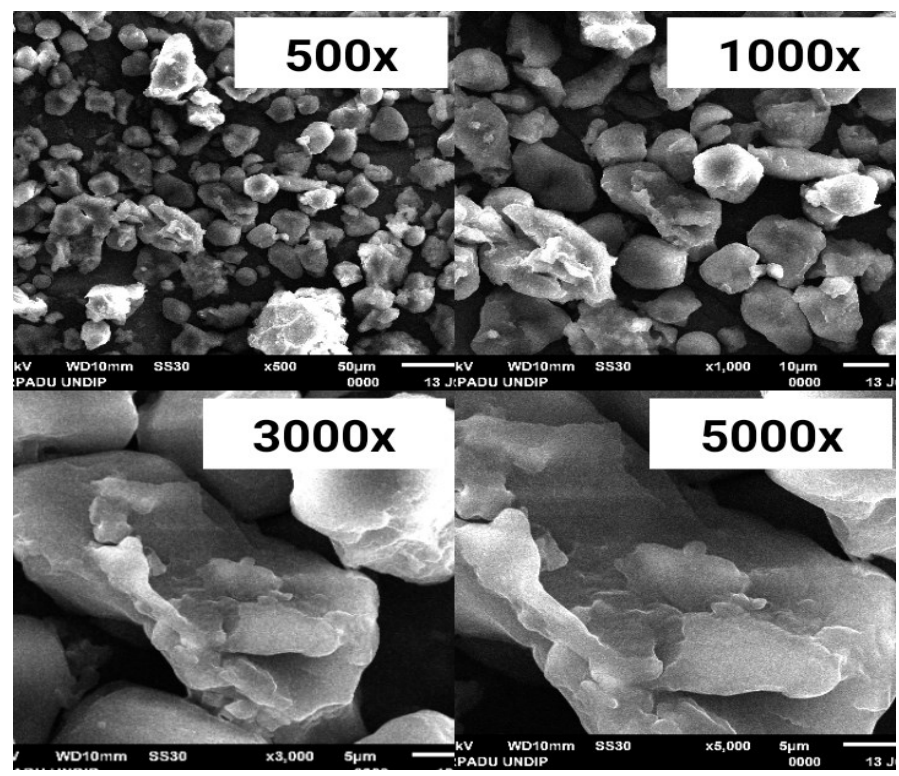

Gambar 2. Penampakan granula kontrol tepung jagung P21

Granula pati jagung mempunyai ukuran berkisar antara $20-120 \mu \mathrm{m}$ dan berbentuk oval polyhedral dengan diameter 6 - $30 \mu \mathrm{m}$ (Singh dkk., 2005). Granula pati jagung memiliki ukuran yang lebih besar dibandingkan dengan ukuran granula padi dan gandum yang berkisar 3-8 $\mu \mathrm{m}$ dan 20-35 $\mu \mathrm{m}$ (Whisler dkk., 1984). Sifat mikroskopis dari granula pati dapat digunakan untuk mengidentifikasi sumber patinya sebab pati yang terdapat dalam jaringan tumbuhan mempunyai bentuk dan ukuran yang khas dan beraneka ragam. Granula pati jagung menunjukkan sifat birefringence, yaitu sifat granula pati yang dapat merefleksikan cahaya terpolarisasi, sehingga dibawah mikroskop polarisasi membentuk bidang warna hitam-putih. Berdasarkan pengamatan yang dilakukan, terlihat bentuk dan sifat birefringence tepung jagung nikstamal pada perlakuan $60 \%$ dengan 24 jam granula lebih kecil untuk merefleksikan cahaya terpolarisasi jika dibandingkan dengan kontrol tepung jagung P21.

\section{KESIMPULAN}

Semakin tinggi konsentrasi $\mathrm{Ca}(\mathrm{OH})_{2}$ dan lama perendaman pada konsentrasi $60 \%$ dan lama perendaman 24 jam akan mengakibatkan meningkatnya nilai kelarutan sebesar (13,04\%), daya serap air sebesar (WHC) $(2,18 \mathrm{~g} / \mathrm{g})$ serta dengan semakin tinggi konsentrasi $\mathrm{Ca}(\mathrm{OH})_{2}$ dan lama perendaman yang diberikan akan mengakibatkan semakin menurunnya nilai kekerasan (tekstur) sebesar (493,19 gr force), swelling power sebesar $(8,23 \%)$, serta menurunkan nilai warna kecerahan $\left(\mathrm{L}^{*}\right)$ sebesar $(60,33)$ dan menurunkan nilai notasi $\left(b^{*}\right)$ menjadi warna kuning sebesar $(53,33)$.

\section{DAFTAR PUSTAKA}

Ambriz, S.L.R., Hernandes, J.J.L., Acevedo, E.A., Tovar, J., dan Perez, L.A.B. 2008. Characterization of a Fibre-Rich Powder Prepared by Liquefaction of Unripe Banana Flour. Journal of Food Chemistry 107, pp. 1515-1521

Balagopalan., Padmaja, C.G., Nanda, S.K. dan Morthy, S.N. 1988. Cassava in Food, Feed, and Industry. CRC Press, Inc.,Boca Raton Florida.

BeMiller, J.N. dan Whistler, R.L. 1997. Carbohydrate in R. Fennema Owen (Ed). Food Chemistry. Ohio State: Columbus.

Choy, Ai-ling., Hughes, J.G. dan Small, D.M. 2010, The Effect of Microbial Transglutaminase, Sodium Steroyl Lactylate and Water on The Quality of Instant Fried Noodles, Journal of Food Chemistry 122:957-964. 
Ferdiansyah, M.K., Pranoto, Y. dan Marseno, D.W. 2018. Characteristics of crude cellulose from plam (Elaeis oleifera) midrib by sodium hidroxide pretreatment. Food Research, 2(3): 258-262. https://doi.org/10.26656/fr.2017.2(3).282

Goldsworthy, P.R. dan Fisher, N.M. 1996. Fisiologi Tanaman Budidaya Tropik. Gadjah Mada University Fress. Yogyakarta. hlm 697-724.

Haryadi, 1999. Hidrokoloid gel. Jurusan Teknologi Pangan dan Hasil Pertanian, Fakultas Pertanian. UGM. Yogyakarta.

Hoover, R. dan Hadziyev, D. 1981. Characterization of Potato Starch and Its Monoglyceride Complexes.Starch/Starke. 33, 290-300.

Hoover, R., dan Sosulski F. 1986. Effect of Cross Linking on Functional Properties of Legume. Starches/Stärke 38: 149-155.

Hutching, J.B. 1999. Food Color and Apearance. Marylan: Aspen publisher Inc.

Jayusmar, E., Trisyulianti dan Jacja, J. 2002. Pengaruh Suhu dan Tekanan Pengempaan Terhadap Sifat Fisik Wafer Ransum dari Limbah Pertanian Suber Serat dan Leguminosa untuk Ternak Ruminansia. Media Peternakan. 24(3): 76-80.

Kainuma, K., Odat, T., Cuzuki, S. 1967. Study of Starch Phosphates Monoesters. J. Technol, Soc. Starch 14: $24-28$.

Keadaan Tanaman Pangan Jawa Tengah Juni. 2017. Dinas Pertanian dan Perkebunan Provinsi Jawa Tengah.

Lingga P. 1995. Bertanam Umbi-Umbian. PT. Penebar Swadaya. Jakarta.

Ma, Z., Boye, J.I., Simpson, B.K., Prasher, S.O., Monpetit, D. dan Malcolmson, L. 2011. Thermal Processing Effects on the Functional Properties and Microstructure of Lentil, Chickpea, and Pea Flours. Articel in Press. Food Research International. 44(8), 2534-2544

Matz, S. 1962. Food texture. The AVI Publishing Co. New York. 573 pp.

Miyazaki., Megumi, V.H., Tomoko, M. dan Naofumi, M. 2006. Recent Advances in Application of Modified Starches for Breadmaking, Trend in Food Science \& Technology 17: 591-599.

Rong, L.I dan Kang-Ning, W. 2009. Nixtamalization Effect on the Contents of Phytic Acid in the Varieties of Maize and the Bioavailability of Iron in Nixtamalized to Young Pigs. Journal of nutrition. 8 (6) : 905-909.

Rosentrater, K.A. 2005. A Review of Corn Masa Processing Residues: Generation, Properties, and Potential Utilization. Journal of Food Science. $26: 284-292$.

Rukmana, R. 2010. Jagung Budidaya, Pascapaen, dan Penganekaragaman Pangan. Aneka Ilmu. CV. Semarang.

Setiawan, I. 2009. Pengaruh Fermentasi Spontan terhadap Sifat Fisikokimia Pati Jagung. Skripsi. Unila.

Singh, N., Sandhu, K.S., dan Kaur, M. 2005. Physicochemical Properties Including Granular Morphology, Amylose Content, Swelling and Solubility, Thermal and Pasting Properties of Starches from Normal, Waxy, High Amylose and Sugary Corn. Progress in Food Biopolymer Research. 1: 43- 55.

Valencia, N.V., Perez, E.G., Acevedo, E.A., Tovar, J., Ruales, J., dan Perez, L.A.B. 2007. Fibre Concentrate from Mango Fruit : Characterization, Associated Antioxidant Capacity and Application as a Bakery Product Ingredient. Journal of LWT, 40, pp. 722-729.

Whisler, R.L. dan Paschall, E.F. 1984. Starch Chemistry and Technology 2nd edition. Academic Press, Inc. USA.

Xu, Y., Miladinov, V., Hanna, M. A. 2004. Synthesis and Characterization of Starch Acetates with High Substitution. Cereal Chemistry. $81: 735-740$. 